\title{
Identification of new long non-coding RNAs associated with medullary thyroid cancer
}

\author{
Luzón-Toro Berta ${ }^{1,2}$, Fernández Raquel $M^{1,2}$, Martos-Martínez Juan Manuel ${ }^{3}$, Antiñolo Guillermo ${ }^{1,2}$ and Borrego Salud ${ }^{1,2 *}$ \\ ${ }^{1}$ Department of Maternofetal Medicine, Genetics and Reproduction, Institute of Biomedicine of Seville (IBIS), University Hospital Virgen del Rocío/CSIC/ \\ University of Seville, Seville, Spain \\ ${ }^{2}$ Centre for Biomedical Network Research on Rare Diseases (CIBERER), Seville, Spain \\ ${ }^{3}$ Endocrine Surgery Unit, General Surgery Department, University Hospital Virgen del Rocío, Seville, Spain
}

\begin{abstract}
Medullary thyroid carcinoma (MTC) represents just 5-10\% of all thyroid malignancies. In contrast to the familial MEN2, little is known about the etiology of sporadic MTC. New approaches are required to elucidate the mechanisms underlying the pathogenesis of sMTC. Long noncoding RNAs (lncRNAs), are wellrecognized post-transcriptional regulators of genetic expression and recent studies have described multiple aberrantly expressed non-coding RNAs in thyroid cancers. In the current study we have aimed to perform the first screening of multiple lncRNAs in tumoral tissues from MTC patients by qRT-PCR. Our analysis showed the association of $15 \mathrm{lncRNAs}$ from which 6 where new in association with this disease (RMST, SNHG16, FTX, GAS5, IPW, MEG3). The association of these new lncRNAs with overall survival was analyzed by Kaplan-Meier curve.
\end{abstract}

\section{Introduction}

Medullary thyroid carcinoma (MTC) it is a tumor originated from C-cells and derived from the neural crest which accounts for only $1 \%-$ $2 \%$ of thyroid cancers, although it is responsible for about $13 \%$ of all thyroid cancer-related deaths $[1,2]$. MTC can occur either sporadically (75\%) or as the dominant component of the type 2 multiple endocrine neoplasia syndromes (MEN2, 25\%). It is considered a rare disease, with an estimated prevalence in the general population of 1/14,300 [http:// www.orpha.net; ORPHA No: 1332].

The broad term long non-coding RNA (lncRNA) refers to a class of non-coding RNA transcript of minimum 200 nucleotides in length. They have gained widespread attention in recent years as new players in transcriptional, epigenetic, or post-transcriptional regulation of gene expression [3]. To date, only one study has examined the expression of lncRNAs in patients with MTC [4]. Consequently, lncRNAs are attractive and promising targets in cancer prognosis and treatment.

The purpose of this study is to bring insight and deeper understanding into the etiology of sMTC, to a deeper understanding of disease mechanisms, pathogenesis, and searching of new therapeutic targets. To afford this aim, we have analyzed the expression of lncRNAs in this type of tumors.

\section{Materials and methods}

\section{Experimental subjects}

In this study, we have performed lncRNA expression analysis on four sMTC cases (Table 1). All MTC tissues and their corresponding adjacent non-tumor thyroid tissues were obtained from these patients after undergoing surgical resection. The samples were snap frozen in liquid nitrogen and stored at $-80^{\circ} \mathrm{C}$ until use. A written informed consent was obtained from all the participants for clinical and molecular genetic studies. The study was approved by the Ethics Committee for
Table 1. Clinicopathological features of included MTC patients

\begin{tabular}{|l|c|}
\hline Characteristics & N \\
\hline Age at diagnosis, years & 46.5 \\
\hline Median (range) & 2 \\
\hline Gender & \\
\hline Male & \\
\hline Female & \\
\hline Inheritance & 4 \\
\hline Sporadic (absence of any mutation MEN2 related) & \\
\hline Tumor size, centimeters & 2.75 \\
\hline $\begin{array}{l}\text { Median (range) } \\
\text { Nodal metastasis at diagnosis }\end{array}$ \\
\hline Distant metastasis & \\
\hline Present at initial diagnosis & 3 \\
\hline
\end{tabular}

clinical research in the University Hospital Virgen del Rocío (Seville, Spain) and complies with The Code of Ethics of the World Medical Association (Declaration of Helsinki), printed in the British Medical Journal (18 July 1964).

\section{Screening by lncRNA PCR Array}

Total RNA was obtained from tissues of our patients and commercial cells by using RNEasy Purification Kit (Qiagen), according to the manufacturer's instructions. The RNA was quantified by Nanodrop (Invitrogen, USA) and $1 \mu \mathrm{g}$ of total RNA was reverse transcribed into

${ }^{\star}$ Correspondence to: Salud Borrego, MD, PhD, Department of Materno Fetal Medicine, Genetics and Reproduction. University Hospital Virgen del Rocío, Maternal Hospital. $2^{\text {nd }}$ floor. Av. Manuel Siurot n/n. 41013, Seville, Spain, E-mail: salud.borrego.sspa@juntadeandalucia.es

Received: February 22, 2019; Accepted: February 27, 2019; Published: March 05,2019 
cDNA using PrimeScript RT Reagent Kit (Perfect Real Time; TaKaRa, Osaka, Japan) to determine lncRNA expression levels, using GAPDH as internal control. For lncRNA expression analysis, laboratory-verified SYBR'Green $\mathrm{qPCR}$ assays ( $\mathrm{RT}^{2}$ lncRNA PCR Array, Qiagen) were used. Each plate contains 84 lncRNAs already associated with different cancer pathways (Supplementary Table 1). The quantitative realtime PCR (qRT-PCR) was performed at the 7900HT Fast Real-Time PCR System with the 384-Well Block Module (Applied Biosystems). We used the $\Delta \Delta \mathrm{Ct}$ method for relative quantitation of lncRNAs level expression, where a fold-change of at least two times and a corrected $\mathrm{P}$-value of $<0.05$ were used as a criterion of selection.

\section{Statistical analysis}

Overall survival rates were calculated by the Kaplan-Meier method with the long-rank test applied for comparison. P-value $<0.05$ was considered as statistically significant.

\section{Results}

The expression profiles of 84 lncRNAs, already associated with different cancer pathways, in 4 tumoral and non-tumoral paired tissues were determined by SYBR Green $\mathrm{qPCR}$ assays. Fifteen differentially expressed lncRNAs were detected in our samples (all adjusted $P \leq$

Table 2. Aberrant LncRNAs in MTC tissues: All significant lncRNAs obtained by qRT-PCR (7900HT Taqman system) through the RT2 lncRNA PCR Arrays. RQ represents the foldchange. From the normalized value of 1.00 of non-tumoral tissues, we represent those lncRNAs downregulated $(<2.00)$ and those ones upregulated $(<2.00)$ in our study. The significant p-value was $<0.05$. All available information about their implication in other type of cancers is also compiled on the last column of the table, with special mention when they have been linked with thyroid cancer.

\begin{tabular}{|c|c|c|c|c|c|c|}
\hline Sample & Detector & $\operatorname{Avg} \mathbf{C t}$ & Avg Delta Ct & $\begin{array}{l}\text { Delta Delta } \\
\text { Ct SD }\end{array}$ & $\mathbf{R Q}$ & $\begin{array}{l}\text { Described in cancer } \\
\text { (is it described into thyroid cancer)? }\end{array}$ \\
\hline Non-tumoral & ZFAS1 & 29.275 & 3.833 & 0.000 & 1.000 & $\begin{array}{l}\text { Not associated with thyroid cancer but it is related with colorectal, gastric, } \\
\text { ovarian, prostate, hepatic, bladder, esophagus and breast cancers. }\end{array}$ \\
\hline Tumoral & ZFASI & 23.903 & 2.997 & -0.836 & 1.785 & \\
\hline Non-tumoral & RMST & 30.659 & 5.217 & 0.000 & 1.000 & Not associated with thyroid cancer but it is related with breast cancer. \\
\hline Tumoral & $R M S T$ & 24.888 & 3.982 & -1.235 & 2.353 & \\
\hline Non-tumoral & SNHG16 & 31.328 & 5.885 & 0.000 & 1.000 & $\begin{array}{l}\text { Not associated with thyroid cancer but it is related with esophageal } \\
\text { squamous cell carcinoma, gastric, lung, glioma, bladder, breast, } \\
\text { colorectal and cervical cancers. }\end{array}$ \\
\hline Tumoral & SNHG16 & 25.200 & 4.294 & -1.591 & 3.014 & \\
\hline Non-tumoral & FTX & 30.498 & 5.056 & 0.000 & 1.000 & $\begin{array}{l}\text { Not associated with thyroid cancer but it is related with hepatocellular, } \\
\text { colorectal, renal, breast cancers as well as in leukemia and melanoma. }\end{array}$ \\
\hline Tumoral & FTX & 23.914 & 3.008 & -2.048 & 4.135 & \\
\hline Non-tumoral & GAS5 & 30.056 & 4.613 & 0.000 & 1.000 & $\begin{array}{l}\text { Associated with thyroid cancer, among other tumors (Low expression } \\
\text { of long non-coding RNA GAS5 is associated with poor prognosis of } \\
\text { patients with thyroid cancer. }\end{array}$ \\
\hline Tumoral & GAS5 & 23.297 & 2.390 & -2.223 & 4.668 & \\
\hline Non-tumoral & $I P W$ & 30.182 & 4.739 & 0.000 & 1.000 & Not associated with thyroid cancer. \\
\hline Tumoral & $I P W$ & 23.908 & 3.002 & -1.738 & 3.335 & \\
\hline Non-tumoral & MALATI & 31.932 & 6.489 & 0.000 & 1.000 & $\begin{array}{l}\text { Associated with different cancers and other pathologies, and with } \\
\text { thyroid cancer (Upregulation of long noncoding RNA MALAT1 in } \\
\text { papillary thyroid cancer and its diagnostic value. Liu J et al. Future } \\
\text { Oncol. } 2018 \text { Jul 10; MicroRNA-21 and long non-coding RNA } \\
\text { MALAT1 are overexpressed markers in medullary thyroid carcinoma. }\end{array}$ \\
\hline Tumoral & MALAT1 & 26.359 & 5.453 & -1.036 & 2.051 & \\
\hline Non-tumoral & $M E G 3$ & 31.919 & 6.477 & 0.000 & 1.000 & $\begin{array}{l}\text { Associated with different cancers and other pathologies, and with } \\
\text { thyroid cancer (Long noncoding RNAs: emerging players in thyroid } \\
\text { cancer pathogenesis. }\end{array}$ \\
\hline Tumoral & MEG3 & 22.835 & 1.928 & -4.548 & 23.397 & \\
\hline Non-tumoral & PTCSC1 & 28.910 & 3.467 & 0.000 & 1.000 & $\begin{array}{l}\text { Associated with thyroid cancer Long noncoding RNAs: emerging } \\
\text { players in thyroid cancer pathogenesis. }\end{array}$ \\
\hline Tumoral & PTCSCI & 26.362 & 5.455 & 1.988 & 0.252 & \\
\hline Non-tumoral & PTCSC 3 & 29.431 & 3.989 & 0.000 & 1.000 & $\begin{array}{l}\text { The polymorphism rs } 944289 \text { predisposes to papillary thyroid carcinoma } \\
\text { through a large intergenic noncoding RNA gene of tumor suppressor type. }\end{array}$ \\
\hline Tumoral & PTCSC3 & 26.283 & 5.377 & 1.388 & 0.382 & \\
\hline Non-tumoral & $T U G 1$ & 29.886 & 4.443 & 0.000 & 1.000 & $\begin{array}{l}\text { LncRNA TUG1 influences papillary thyroid cancer cell proliferation, } \\
\text { migration and EMT formation through targeting miR-145. }\end{array}$ \\
\hline Tumoral & $T U G 1$ & 24.500 & 3.593 & -0.849 & 1.802 & \\
\hline Non-tumoral & ADAMTS9-AS2 & 31.702 & 6.259 & 0.000 & 1.000 & $\begin{array}{l}\text { Not associated with thyroid cancer but it is related with lung and } \\
\text { glioma cancers. }\end{array}$ \\
\hline Tumoral & ADAMTS9-AS2 & 27.908 & 7.002 & 0.743 & 0.598 & \\
\hline Non-tumoral & PRNCRI & 31.918 & 6.475 & 0.000 & 1.000 & $\begin{array}{l}\text { Not associated with thyroid cancer but it is related with gastric, } \\
\text { colorectal and prostate cancers. }\end{array}$ \\
\hline Tumoral & PRNCRI & 28.308 & 7.402 & 0.927 & 0.526 & \\
\hline Non-tumoral & $R M R P$ & 22.623 & -2.820 & 0.000 & 1.000 & $\begin{array}{l}\text { Not associated with thyroid cancer but it is related with breast, lung, } \\
\text { gastric and colon cancers. }\end{array}$ \\
\hline Tumoral & $R M R P$ & 18.382 & -2.524 & 0.295 & 0.815 & \\
\hline Non-tumoral & $H 19$ & 31.640 & 6.197 & 0.000 & 1.000 & $\begin{array}{l}\text { Associated with thyroid cancer, among other tumors (Epigenetic } \\
\text { Modifications in Thyroid Cancer Cells Restore NIS and Radio-Iodine } \\
\text { Uptake and Promote Cell Death. }\end{array}$ \\
\hline Tumoral & $H 19$ & 27.891 & 6.984 & 0.787 & 0.580 & \\
\hline
\end{tabular}


0.05). From all the differentially expressed lncRNAs, 8 downregulated and 7 upregulated lncRNAs had not been published yet in association with any thyroid carcinoma (Table 2).

In addition, analysis of overall survival was performed by using Kaplan-Meier curve although it is not significant (available under request).

\section{Discussion}

Many efforts are being made to establish the biological and clinical relationships between lncRNAs and cancer. They are involved in a variety of biological processes through the regulation of gene expression $[5,6]$. In this manner, lncRNAs regulate transcription and epigenetic events, leading cells adapting to a changing environment.

It is important to highlight that one of the upregulated lncRNAs that we have obtained in this study was MALAT1, which has been already associated with MTC [4]. This fact reinforces the validity of our approach. In this study, we have evaluated 84 different lncRNAs, already associated with cancer pathways, in 4 MTC patients through qRT-PCR, showing the significant association of 3 downregulated and 4 upregulated new lncRNAs that had not been published yet in association with neither MTC nor any thyroid carcinoma.

This study is not devoid of limitations. We have compared by qRTPCR the expression levels of different lncRNAs in a group of MTC patients and normalizing to the levels detected in normal adjacent thyroid tissues (with mostly follicular cells). Although normal C-Cells would be our perfect control tissue, there is very little number of them in the normal thyroid. Thus, we decided to use thyroid follicular cells because they are very close to the MTCs and they express the thyroid transcription factor 1, as well as C-Cells do. Then, we consider that this comparison approach was a good alternative, as some previous studies also confirmed $[4,7,8]$.

\section{Conclusions}

We describe here six new lncRNAs (RMST, SNHG16, FTX, GAS5, $I P W, M E G 3)$ which could play an interesting role in this rare tumor, that to date has any effective therapy or prognosis. Further studies with larger sample sizes would be needed to confirm the role of these new lncRNAs in MTC that maybe can serve as predictive cancer biomarkers or targets for preventive drugs.

\section{Data availability}

The expression data from the qPCR assays used to support the findings of this study are available from the corresponding author upon request.

\section{Conflicts of interest}

The authors declare that there is no conflict of interest regarding the publication of this article.

\section{Funding statement}

This study was supported by Instituto de Salud Carlos III (ISCIII), Spanish Ministry of Economy and Competitiveness, Spain and cofunded by European Union (ERDF/ESF, "Investing in your future") [PI16/0142]. In adittion, it has been funded by the Regional Ministry of Innovation, Science and Enterprise of the Regional Government of Andalusia [CTS-7447]. CIBERER is an initiative of the ISCIII, Spanish Ministry of Economy and Competitiveness.

\section{Acknowledgments}

The authors thank the patients that have participated in this study, as well as the donors and the Hospital Universitario Virgen del RocíoInstituto de Biomedicina de Sevilla Biobank (Andalusian Public Health System Biobank and ISCIII-Red de Biobancos PT13/0010/0056) for the human specimens used in this study.

\section{Supplementary material}

Supplementary table 1: The 84 lncRNAs from the $\mathrm{RT}^{2} \operatorname{lncRNA}$ PCR Arrays.

\section{References}

1. Noone AM, Cronin KA, Altekruse SF, Howlader N, Lewis DR, et al. (2017) Cancer Incidence and Survival Trends by Subtype Using Data from the Surveillance Epidemiology and End Results Program, 1992-2013. Cancer Epidemiol Biomarkers Prev 26: 632-641. [Crossref]

2. Kebebew E, Ituarte PH, Siperstein AE, Duh QY, Clark OH (2000) Medullary thyroid carcinoma: clinical characteristics, treatment, prognostic factors, and a comparison of staging systems. Cancer 88: 1139-1148. [Crossref]

3. Huarte M (2015) The emerging role of lncRNAs in cancer. Nat Med 21: 1253-1261 [Crossref]

4. Chu YH, Hardin H, Schneider DF, Chen H, Lloyd RV (2017) MicroRNA-21 and long non-coding RNA MALAT1 are overexpressed markers in medullary thyroid carcinoma. Exp Mol Pathol 103: 229-236. [Crossref]

5. Haemmerle M, Gutschner T (2015) Long non-coding RNAs in cancer and development: where do we go from here? Int J Mol Sci 16: 1395-1405. [Crossref]

6. Terracciano D, Terreri S, de Nigris F, Costa V, Calin GA, et al. (2017) The role of a new class of long noncoding RNAs transcribed from ultraconserved regions in cancer. Biochim Biophys Acta Rev Cancer 1868: 449-455. [Crossref]

7. Mian C, Pennelli G, Fassan M, Balistreri M, Barollo S, et al. (2012) MicroRNA profiles in familial and sporadic medullary thyroid carcinoma: preliminary relationships with RET status and outcome. Thyroid 22: 890-896. [Crossref]

8. Starenki D, Hong SK, Lloyd RV, Park JI (2015) Mortalin (GRP75/HSPA9) upregulation promotes survival and proliferation of medullary thyroid carcinoma cells. Oncogene 34: 4624-4634. [Crossref]

Copyright: (C2019 Luzón-Toro B. This is an open-access article distributed under the terms of the Creative Commons Attribution License, which permits unrestricted use, distribution, and reproduction in any medium, provided the original author and source are credited. 